\title{
多重水素結合を利用した結晶性㵶維および マイクロチューブの非共有結合的構築
}

\author{
清 水 敏 美 \\ 物質工学工業技術研究所 巴305-8565 茨城県つくば市東 1-1
}

(1997 年 10 月 31 日受理)

\section{Noncovalent Construction of Crystalline Fibers and Microtubes via Multiple Hydrogen Bonds}

Toshimi SHIMIZU

National Institute of Materials and Chemical Research

1-1 Higashi, Tsukuba, Ibaraki 305-8565

(Received October 31, 1997)

\begin{abstract}
Amphiphiles self-assemble in water to form molecular bilayers. Their head-group arrangements can be considered to be fluidlike. This character is quite different from that of usual 3-D crystals. In this paper, self-assembling properties and morphologies of synthetic dumbbell-shaped amphiphiles (bolaamphiphiles) have been discussed. In particular, the effect of multiple hydrogen bonds on the supramolecular structures were commented. The D-glucose- and oligoglycine-based bolaamphiphiles self-assembled in water to form well-defined fibrous and vesicle-encapsulated tubular assemblies, respectively. The formation strongly depends on the length and even or odd carbon numbers of the spacer alkylene chains. FT-IR spectroscopy, X-ray diffraction and crystal analyses showed that the utilization of multiple hydrogen bonds provides the assemblies with an interesting self-assembling morphology and crystalline surfaces. These crystalline assemblies can rearrange to form 3-D crystals by converting the hydrogen-bonded scheme. Possible selfassembling models for the molecular arrangements within the fibers and tubes were proposed as a result of various solid analyses.
\end{abstract}

\section{1.は じめに}

両親媒性化合物は水中で自己集合し，二分子膜構造を 与える"。この時, 疎水性効果は分子同士の会合を引き 起こし膜構造を安定化させる。一方，水和斥力や立体的 相互作用は大きな三次元結晶の形成を妨げる2)。その結 果, シート状二分子膜構造, 球状ベシクルやミセル構造 といった有限の特異的な形態をもつ自己集合体が出現す る。これら集合体表面の親水性頭部の配列は流動的であ ると考えられる（Fig. 1)。しかし，最近になってその表 面が結晶的（固体的）な分子集合体の存在が見つかって きだ)。これは分子中に導入された水素結合性官能基が 二分子膜界面近傍で水素結合鎖 (あるいはネットワーク) を形成し，水和を抑えるためである。Fuhrhop らの系統 的研究4)方，Fig. 2 に結晶性の表面をもつ脂質集合体
の例をあげる。もし，ミセル頭部が結晶化すればディス ク状ミセル（D）を形成し，これは棒状集合体（R）に 変化する。ミセル（M）やベシクル（V）の頭部が表面 で強い相互作用をもつと二分子膜シート（S）になり， それが大きな曲率をもつことでヘリカルリボン（H）や チューブ（T）に形態変化する。それでは，方向性のあ る水素結合を膜構造の界面近傍で多重に形成させるとそ の自己集合様式，集合形態はどうなるであろうか？ 本 稿では, 筆者らの研究を中心に, まずはじめに材料設計 の立場から見た水素結合の特徴を述べ，続いて水中で得 られるキラルならせん状繊維やチューブといった特異的 構造体の集合様式，構造体中の分子配列，層状構造の界 面での三次元水素結合ネットワークについて最近の話題 を紹介してみたい。 


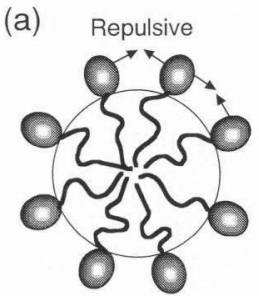

FLUID (b)

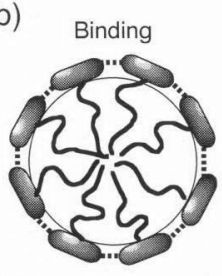

SOLID

Fig. 1 Schematic representation of cross-sections through (a) a fluid micellar rod and (b) a solid micellar rod with a crystalline surface.

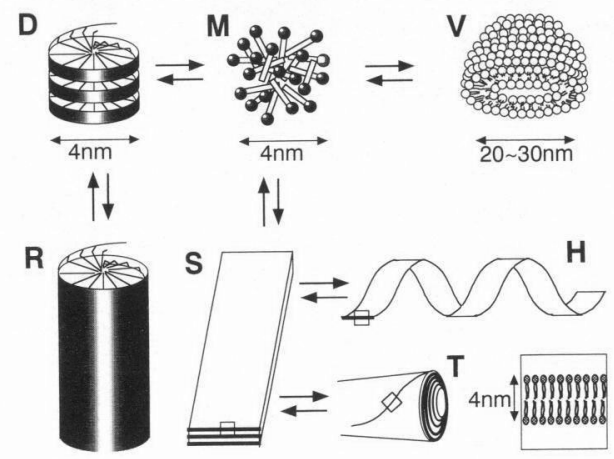

Fig. 2 Spherical micelles (M) and vesicles (V) characterized by repulsive interactions of the head groups. (D): Disk micelles, (R): Bilayer rods, (S): Bilayer sheets, (H): Helical ribbons, and (T): Tubules.

\section{2. 材料設計の立場から見た水素結合の特徴 5}

水素絬合 $(\mathrm{X}-\mathrm{H} \cdots \mathrm{Y})$ は，電気陰性度が高い2つの 原子 $\mathrm{X}, \mathrm{Y}$ を水素原子 $\mathrm{H}$ が結びつけた時生じ，その性 質は主に静電的なものである。共有結合は明確な結合距 離, 結合力, 方向性をもつのに対し, 水素結合は 20 倍〜 30 倍程弱い。また, 結合を $0.1 \AA$ 伸ばすのに必要なエネ ルギーは水素結合の方が約 30 倍小さく, そのため, 水 素結合は伸びやすく，曲がりやすい (方向性)。また， 水素結合の特性は結合周辺の原子まで含めた全ての環境 に大きく依存する (グループ性, 相補性)。水素結合は 連続したネットワークを形成することが可能であり，そ の場合, 単独の水素結合エネルギーの和より大きくなる （協同性）という特徵をもつ。

\section{3. 双頭型糖脂質の分子設計}

2 節で述べた水素結合の弱い方向性，相補性，協同性 などの特徵を生かして分子複合体や分子集合体を構筑す る研究例は Lehn ${ }^{6}$ や Whiteside ${ }^{7}$ などの総説に見られるよ

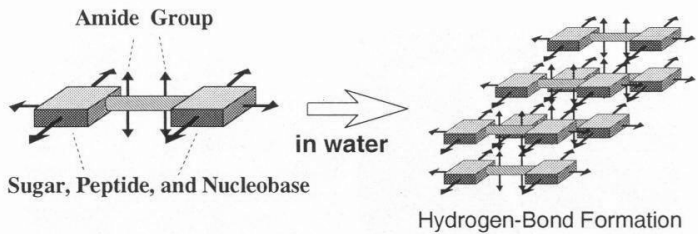

Fig. 3 Supramolecular assemblies of synthetic bolaamphiphiles via multiple hydrogen-bonded networks.

らにこれまでに数多くある。しかし，そのほとんどは非 プロトン性有機溶媒中での水素結合形成であるか, ゲル 状態, 液晶相, 結晶格子中の水素結合様式の制御に限ら れる。それらの詳細は本特集での他の解説を参照された い。また水素結合の相補性に関しては本特集の君塚らの 解説を参照されたい。

筆者らは, 方向性のある水素結合が分子の両端で多重 に, かつ協同的に形成されるように親水性部位として糖, ペプチドなどを導入し，それを疎水性の炭化水素鎖の両 端でアミド結合で連結させる双頭型脂質を設計した (Fig. 3)。一般に水素結合ネットワークの安定性は水素 結合力とその数を増加することにより増大する8)。また， 双頭型の脂質は好熱性細菌や古細菌の細胞膜成分として 含まれ，(1）多形現象がない，(2) 最も薄い単分子膜形 成が可能である，（3）親水部の非対称化によりベシクル 膜を容易に形成する，(4) 膜融合が起こりにくい，など の特徵をもつ9。こうして両親媒性分子を双頭型にする ことにより, 膜構造自身の安定化効果も期待できる。

\section{4. 双頭型糖脂質のキラル瀻維形成}

両端に D-グルコース残基をもつ双頭型糖脂質（Glc-nGlc）は水中で，分子の自己集合により柔軟性のある繊

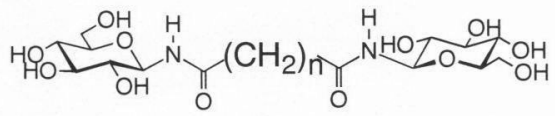

Glc-n-Glc ( $\mathrm{n}=6,9,10,11,12,13$, and 14)

維状あるいは無定形状の結晶性構造体を与える ${ }^{10)}$ 。その 形態は連結部であるアルキレン鎖長の長さおよびその炭 素偶奇数に強く依存した (Fig. 4)。従来, 光学活性な両 親媒性化合物が鏡像体関係にあるキラル分子集合体を与 え, ラセミ混合物がキラルのない平板状集合体を与える 現象が知られる ${ }^{4,11}$ 。今回の結果は従来と異なり, 初め てキラル/非キラル構造体が連結炭化水素鎖の炭素偶奇 数に応じて制御されたことを示している ${ }^{12)}$ 。それでは, これら偶奇効果および構造体の安定性が超分子繊維内の 分子配列の何に起因しているのであろう？ 

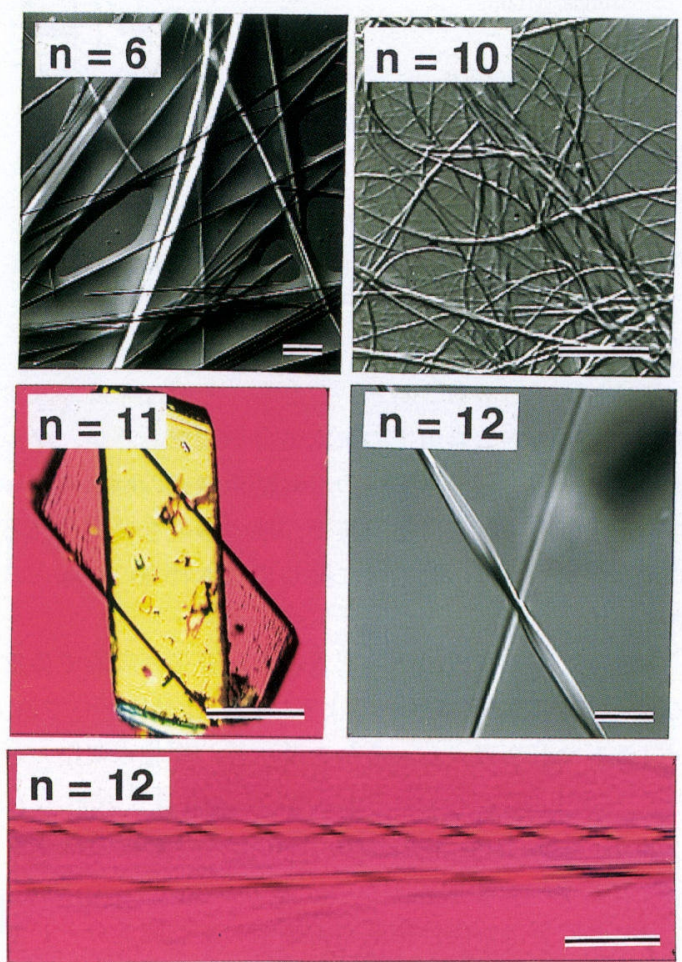

Fig. 4 Supramolecular fibrous assemblies ( $n=6,10$, and 12) and twin crystal $(n=11)$ of GIc-n-Glc observed using confocal laser scanning and polarized light microscopy (at $25^{\circ} \mathrm{C}$, in water). Scale bar $=10 \mu \mathrm{m}$.
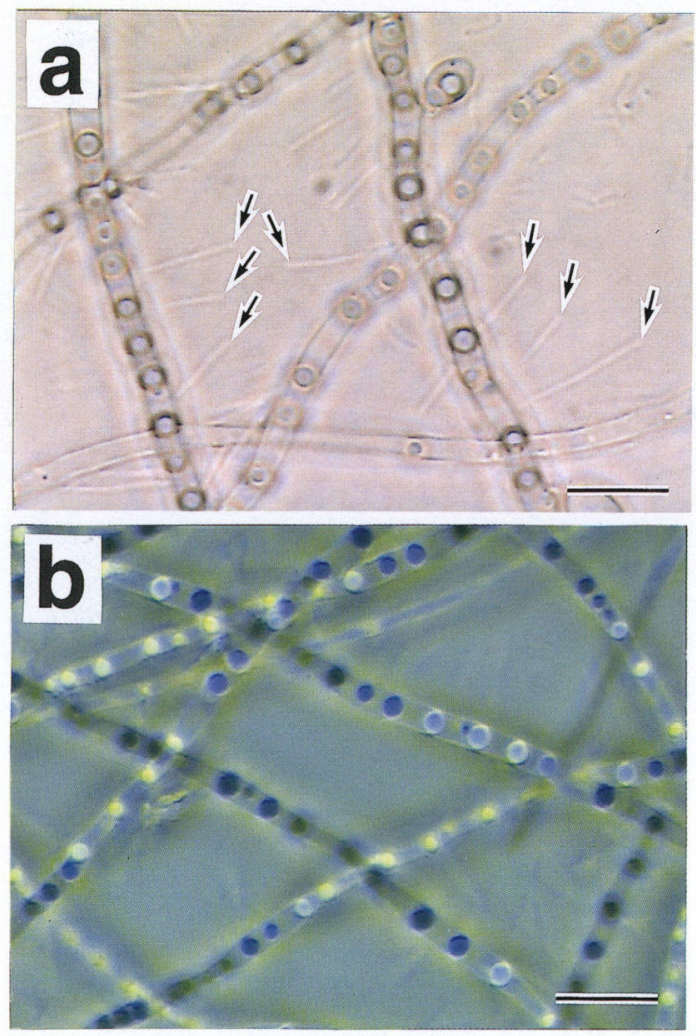

Fig. 11 Vesicle-encapsulated microtubes observed using (a) phase-contrast and (b) dark-field light microscopy (at $25^{\circ} \mathrm{C}$, in water). Needle microcrystal sitting on the outer surface of the tubes are denoted by arrows in (a). Scale bar $=5 \mu \mathrm{m}$.

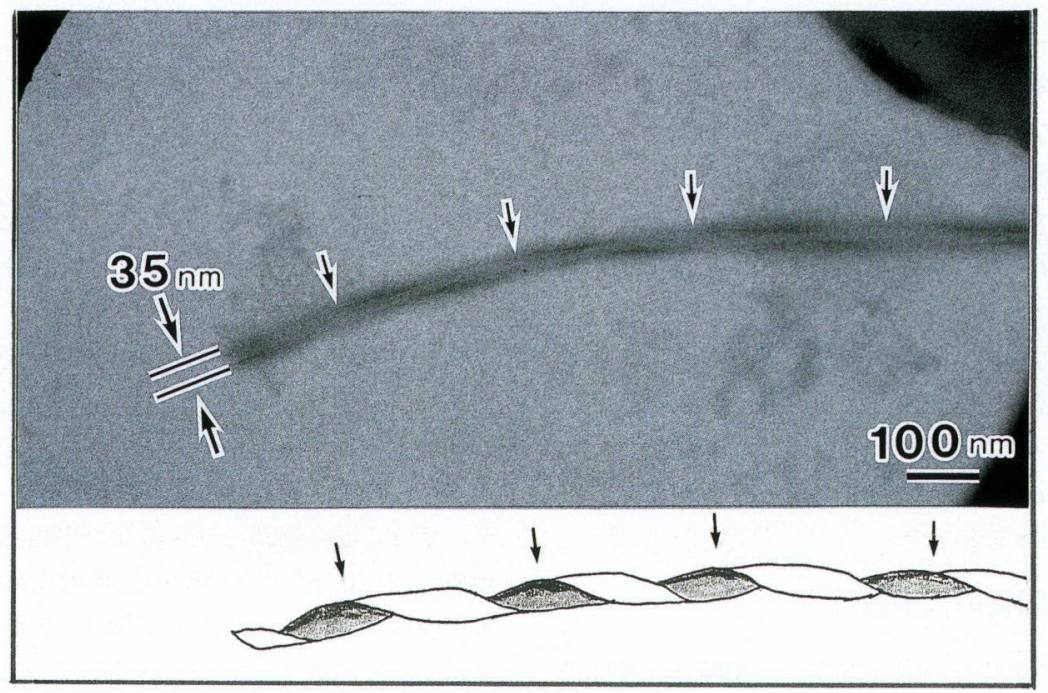

Fig. 8 Transmission electron micrograph of a supramolecular fiber unit made of Glc-12Glc (negatively stained with $2 \%$-phosphotungstic acid). 
(a)

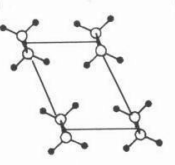

$\mathrm{T} / 1$

(c)

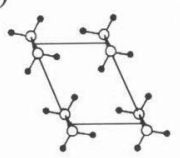

$\mathrm{M} / /$ (b)

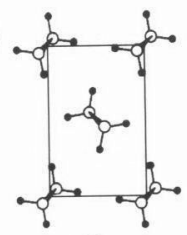

$\mathrm{O} \perp$

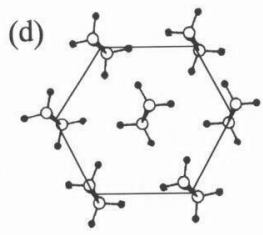

$\mathrm{H}$ (distorted)

Fig. 5 Representative molecular arrangements of oligomethylene chains in fatty acid crystals and derived lipids.

一般に，長鎖の脂質結晶に見られる副格子構造は最近 接する炭化水素鎖のジグザグ鎖面が垂直，平行，無秩序 であるかの違い, さらに空間群対称性の違いにより, 主 に三斜晶系平行型（T / ） および斜方晶系垂直型 $(\mathrm{O} \perp)$ が，それ以外に単斜晶系平行型 $(\mathrm{M} / /)$ やへキサゴナ ル型 $(\mathrm{H})$ などが知られている $\left(\right.$ Fig. 5) ${ }^{13)}$ 。これらの同 定は, 粉末 X 線回折の広角領域における特性回折ピー クや赤外吸収スペクトルのメチレンはさみ振動 $\delta\left(\mathrm{CH}_{2}\right)$ および横摇れ振動 $\mathrm{r}\left(\mathrm{CH}_{2}\right)$ の特性ピークの解析から可能 である ${ }^{14)}$ 。その結果，偶数鎖をもつ双頭型脂質では炭化 水素鎖の副格子が $\mathrm{O} \perp$ 又は $\mathrm{M} \|$ をとり, 奇数鎖では $\mathrm{T} \|$ のパッキング様式をとることが推定できた。また，種々 の固体分析は繊維内のアミド基の配向, 水素結合の強さ, 長周期間隔などに対して偶奇効果による明確な相違を示 した ${ }^{12)}$ ここして，上記の集合体形態に対する偶奇効果 は, 分子が繊維内で形成する層状構造配列の相違（平行 型かプリーツ型）に起因する界面での糖鎖水素結合のキ ラル/非キラル性によるものと考えられる。

\section{5. 䄉維中の分子配列と三次元水素結合ネット ワーク}

双頭型糖脂質として初めて見いだされた Glc-11-Glc の結晶構造は分子がプリーツ状の層状構造を形成してい た。層内にはアミド基と糖鎖 2 位の水酸基が関与した一 次元的な水素結合ネットワーク, 層間にはそれと直交す る面内に拈いて残りの糖鎖水酸基が関与した二次元的な 水素結合ネットワークが形成していた（Fig. 6) ${ }^{15)}$ 。両端 の D-グルコース残基を D-ガラクトース残基に置換する と, 糖鎖間水素結合ネットワークは二次元的から三次元 的に大きく変化する ${ }^{16)}$ 。現在までに, 単糖でかつ一本鎖 型（炭化水素炭素数が 5 以上）の糖脂質の結晶構造は全
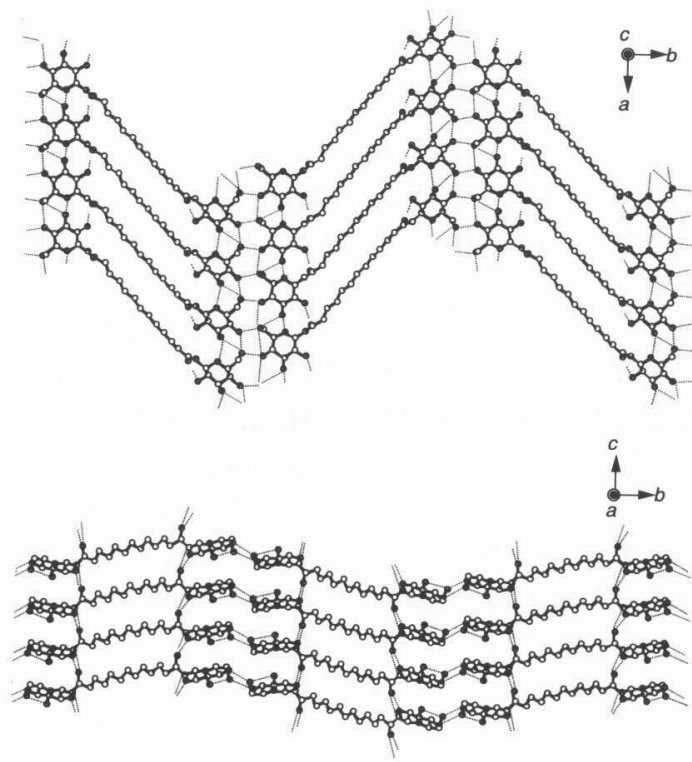

Fig. 6 X-ray crystal structure of Glc-11-Glc, viewed along the $c$-(upper) and the $\alpha$-axis (lower). Hydrogenbonded networks are denoted by dotted lines.

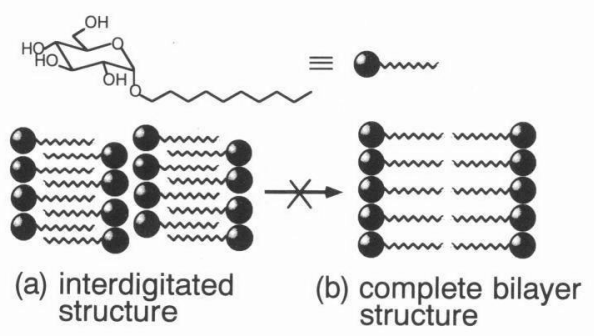

Fig. 7 Crystal structure of 1-decyl- $\alpha$-glucopyranoside.

て完全二分子膜構造をとらずに, 疎水部のアルキル鎖が 指組構造（interdigitated）をした頭-頭不完全二分子膜構 造をとることがわかっている (Fig. 7) ${ }^{17)}$ 。しかし，2つ の糖残基を 1 本の炭化水素鎖で連結した双頭型糖脂質で はこのような指組構造をとることができない。そこで分 子は大きく傾いた層状構造をとることによって最密充填 しているのである。

次に, Glc-12-Glc から形成した超分子繊維内の分子配 列について考えてみよう。これまでに脂質から形成され る繊維内での分子配列を解明した報告は極めて少な ( $^{18)}$ 。筆者らの知る限り, 幅が数百 $\mathrm{nm} \sim$ 数 $\mu \mathrm{m}$, 長さが 数百 $\mu \mathrm{m}$ 数 $\mathrm{cm}$ 程の光学顕微鏡サイズをもつ緎維構造 体を水中から単離した唯一の例に, イソフタル酸長鎖エ 一テル誘導体を用いた例 ${ }^{19}$ がある。彼らはカルボン酸間 の水素結合により分子が環状に配列したディスクモデル を提唱したが，詳細は不明のままである。これに対し， 
Glc-12-GIc から形成される超分子瀻維の基本単位は, 透 過型電子顕微鏡観察より厚さ約 $3 \mathrm{~nm}$ の単分子膜りボン が直径 $35 \mathrm{~nm}$ の右卷きらせんを形成した繊維状構造体 であることがわかった（Fig. 8)。他の固体分析結果も考 慮して Fig. 9 に示した超分子瀻維中 $(n=12)$ の三次元 分子配列を推定した ${ }^{12)}$ 。興味あることに，この基本単位 繊維が 8 本束なりより高次の繊維集合体に会合している 様子がクライオ電顕より確認できた ${ }^{20)}$ 。うしてコラー ゲン繊維などの繊維状タンパク質と同様な階層的な高次 構造化による超分子緎維形成（Fig. 10）が明らかとなっ た。さらに，クライオ電顕像は基本瀻維の半径約 $50 \mathrm{~nm}$ 周囲に存在する水分子はそれより外部にある自由水とは 異なり，繊維表面で形成された糖鎖間水素結合ネットワ 一クの影響を受けて束䋠された水分子結晶格子を形成し ていることも示唆した ${ }^{20)}$ 。
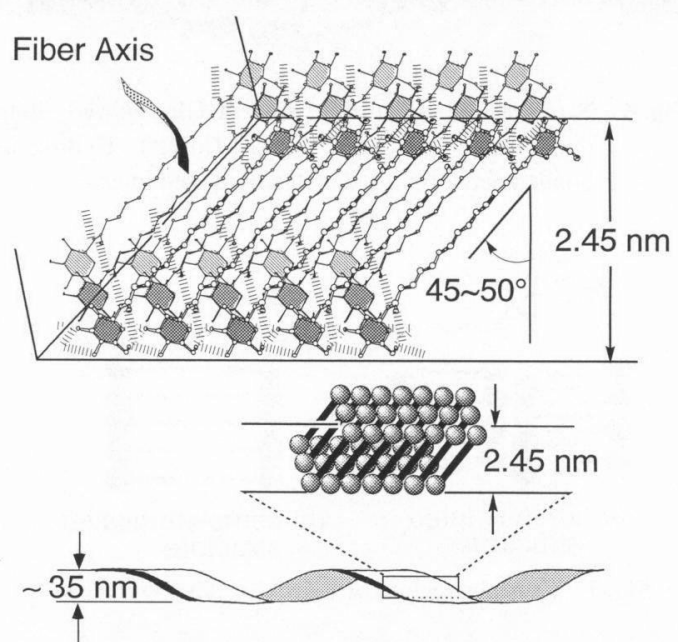

Fig. 9 A possible self-assembling model of Glc-12-Glc based on monolayered chiral sheet. The hydrogenbonded networks between the sugar-head groups are tentatively depicted by reference to those in the crystal structure of Glc-11-Glc ${ }^{15}$.

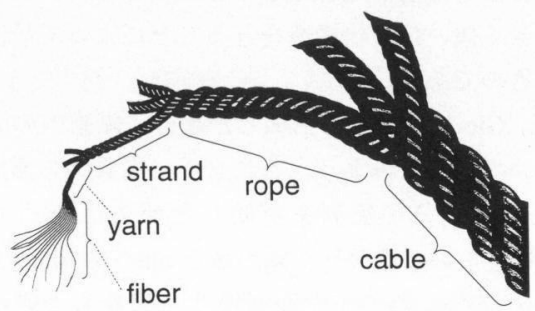

Fig. 10 Schematic drawing of the twisted rope that shows hierarchical fibrous assemblies. In the fiber formation of Glc-12-Glc, the transmission electron microscopic image may correspond to this fiber, whereas optical microscopic image to this cable.

\section{6. 双頭型ペプチド脂質のマイクロチューブ形成}

糖鎖の代わりにオリゴペプチド鎖を導入すると構造体 形成にどのような影響を与えるだろうか？ アミノ酸残 基であるグリシンの二量体または三量体を両端にもつ双 頭型ペプチド脂質（ジカルボン酸型）（C（n) $\left[\mathbf{G l y}_{2}\right]_{2} ）$ の<smiles>CC(=O)NCC(=O)NCC(=O)NCC(=O)O</smiles>

$\mathbf{C}(\mathbf{n})\left[\mathrm{Gly}_{2}\right]_{2}(\mathrm{n}=6$ and 10$)$

ナトリウム塭は，水中で，内部に多数の球状小胞体（べ シクル）を内包する直径が $1 \sim 3 \mu \mathrm{m}$ ，長さが数百 $\mu \mathrm{m}$ の 閉じたチューブ状構造体を与えた (Fig. 11) ${ }^{21)}$ 。さらに, チューブ外壁から極微小の針状結晶が析出している様子 も観測できた。合成脂質が形成する径のより細いチュー ブ状構造体の存在は電顕観察などから数例報告があ る22)。しかし，小胞体をカプセル化した光学顕微鏡サイ ズの単離可能な有機マイクロチューブは従来全く報告例 がない。チューブ状形態は水中での $100^{\circ} \mathrm{C}$ までの加熱 や超音波処理によっても破壊されないぐらい安定であっ た。問題はどのようにして，しかもどんな分子配列でこ うした厚さ数十 $\mathrm{nm}$ 数百 $\mathrm{nm}$ の有機薄膜からなるマイ クロチューブが生成するかである。

末端カルボン酸のイオン化状態，アミド基の水素結合 形成の有無などを強く反映する赤外吸収スペクトルを測 定した結果, 最初溶解していた末端カルボン酸アニオン が何らかのプロトン種，おそらく空気中の二酸化炭素に よってゆっくりとプロトン化し，酸-アニオン型の分子 間水素結合がチューブ膜内に形成していることがわかっ た。一般に長鎖脂肪酸の水中における物理的性質はカル ボキシル基のイオン化度（ $\alpha$ ）に大きく依存する ${ }^{23)}$ 。例 えば，完全にイオン化した脂肪酸（石喃） $(\alpha=1.0)$ は

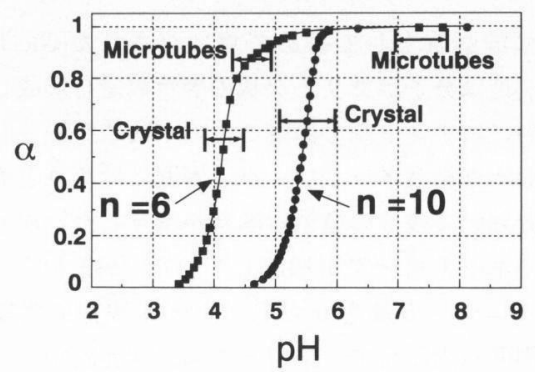

Fig. 12 Ionization degree (a) of $\mathbf{C}(\mathbf{n})\left[\mathbf{G l y}_{2}\right]_{2}(n=6$ and 10) as a function of $\mathrm{pH}$. 
(a)

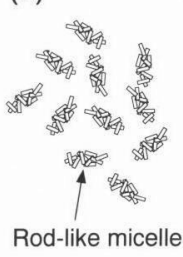

(b)

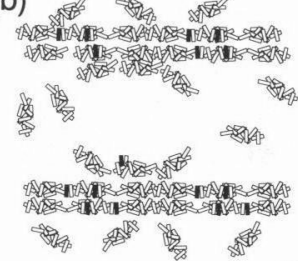

(c)

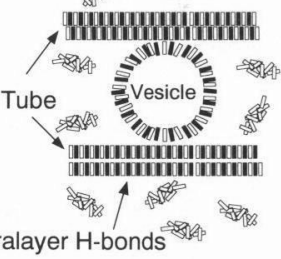

(d) 20
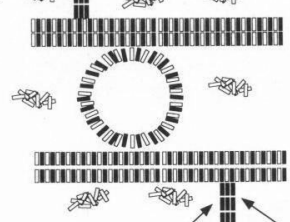

Interlayer H-bonds Crystal

$\square \equiv{ }^{-} \mathrm{OOC}-\mathrm{COO}^{-}$

$\equiv \mathrm{HOOC} \longrightarrow \mathrm{COOH}$

Fig. 13 Possible mechanism for the formation of vesicle-encapsulated microtubes and needle crystals on the outer surface.

(a) Intralayer acid-anion dimers

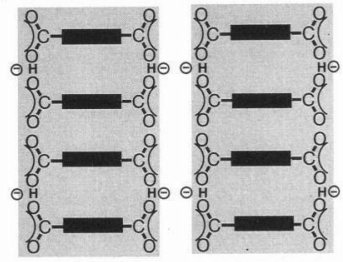

(b) Interlayer acid-acid dimers

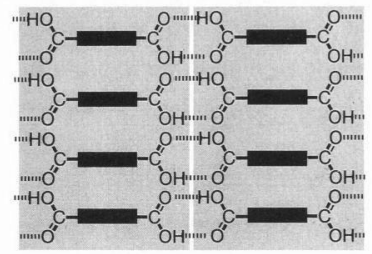

Fig. 14 Schematic representation of (a) intralayer acid-anion and (b) interlayer acid-acid dimers that lead to the formation of microtubes and needle crystals, respectively.

水中でミセル, 液晶, 希に結晶を形成するのに対し, 全 くイオン化していない脂肪酸 $(\alpha=0)$ は油滴又は結晶 を形成する。しかし，イオン化度がその中間值（ $0<\alpha$ く1.0）をとる時の集合挙動については不明な点が多い。 今回用いた双頭型ペプチド脂質について水溶液の $\mathrm{pH}$ と イオン化度 $(\alpha)$ との相関を求めた (Fig. 12)。 $n=6$ の 場合を例にとると, 水中で, $\alpha=0.8 \sim 0.9$ でマイクロチ ユーブ形成が起こり, それ以降プロトン化が進行（ $\alpha<$ 0.7）すると結晶化が起こることがわかった。

\section{7. チューブの生成プロセス}

以上の解析をむとに，マイクロチューブおよびチュー ブ上に析出した微小針状結晶の生成プロセスを推定する ことが可能である(Fig. 13) ${ }^{24)}$ 。最初にロッド状ミセル として溶解していたカルボン酸アニオン型脂質は, 酸一 アニオン型の分子間水素結合形成（Fig. 14）とグリシン 残基間の分子間水素結合形成により，チューブ状構造体

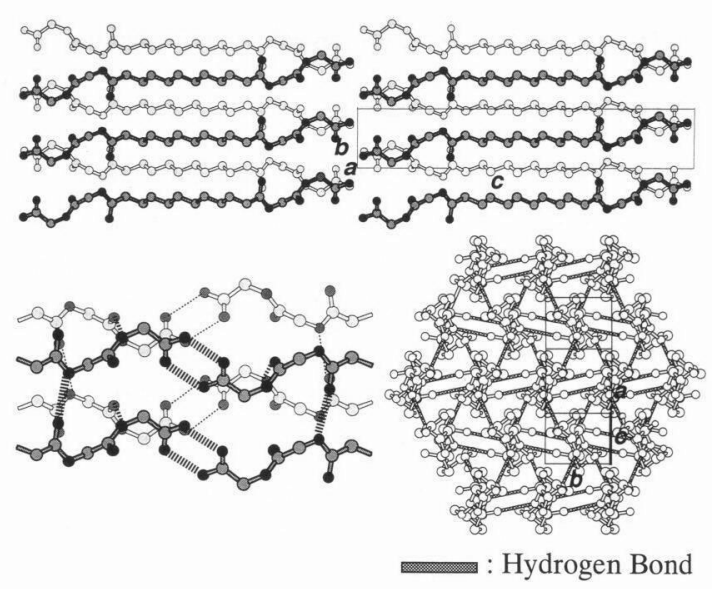

Fig. 15 Crystal structure of $\mathbf{C}(\mathbf{1 0})\left[\mathbf{G l y}_{2}\right]_{2}$. (a) projected on the $b c$-plane, (b) magnification of the terminal glycylglycine moieties, and (c) projected on the $b(2 a)$ $3+1 c / 8)$-plane.

を形成する。さらに, プロトン化が進むと，チューブ外 壁界面において酸-酸型への水素結合様式の変換が生じ, 極微小の針状結晶がチューブ外壁に析出したと考えられ る。注目すべきことは, チューブ形成における $\alpha$ が $0.8 \sim$ 0.9 であることから, 溶解したプロトンはチューブの膜 界面に濃縮され, 界面付近で局所的な $\mathrm{pH}$ の減少が起き ていることである。一方, チューブ内部の球状ベシクル はチューブ内壁における内層部の層状欠陥を契機として エネルギー的により有利に生成したのではないかと考え られる。

\section{8. 結晶とチューブの三次元水素結合ネット ワーク}

酢酸の蒸気拡散法により得た双頭型オリゴグリシン脂 質 $\mathbf{C}(\mathbf{1 0})\left[\mathrm{Gly}_{2}\right]_{2}$ の結晶構造は分子が層状構造をとり， 分子同士は層間で酸-酸型の分子間水素結合を形成して いた ${ }^{25}$ 。分子は最近接する周囲の 6 分子とグリシン残基 


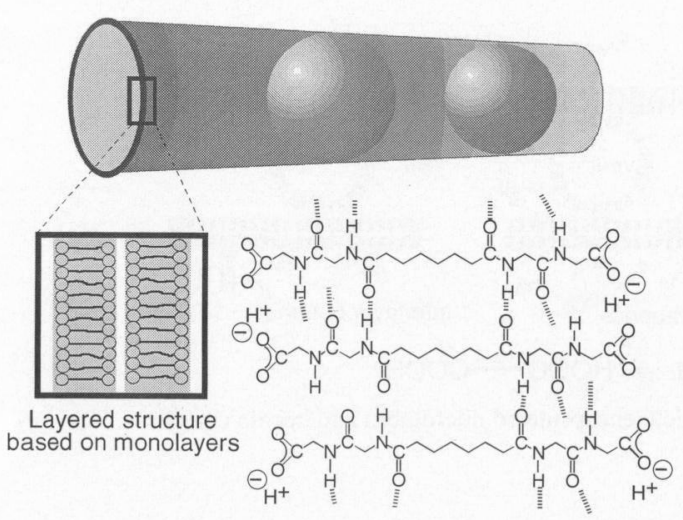

Fig. 16 A possible molecular arrangement within the organic microtubes.

のアミド基間で三次元的な分子間水素結合を形成し， へ キサゴナル格子をとる（Fig. 15）。高分子であるポリグ リシンが同様なへキサゴナル格子（ポリグリシン II 型 構造）を形成することが知られ ${ }^{26)}$ ，この結果は低分子の 自己集積により初めて高分子の三次元構造を自発的に形 成したことを意味する。一方, チューブ状構造体におい ては, 分子は膜内で層状構造をとるが, 結晶中での分子 配列とは異なり層内での酸一アニオン型水素結合とグリ シン残基間の一部が切れた分子間水素結合によって特徴 ゔけられる分子配列（Fig. 16）をとることが固体分析よ り推定できた。すなわち, 脂質分子間の層状界面および 単分子膜内における水素結合の微妙な組み合わせの相違 だけでマイクロチューブあるいは結晶が生成することが 見いだされた。

\section{9.お わり に}

全く同じジカルボン酸の両端にアミド結合を介して単 糖であるアルドピラノース残基またはオリゴグリシン鎖 を導入し, 水中での自己集積を検討した。その結果, 全 く異なる形態をもつ構造体と集積挙動を示した。これは まさしく, 親水部にある水素結合性をもつ水酸基やアミ ド基の方向性, 協同性の相違, 言い換えれば水素結合様 式の相違が直接的に集積形態に反映したものである。ま た，水素結合部位を分子両端に多重に導入した結果，よ り結晶性の高い親水部界面をもつ構造体を形成すること がわかった。本稿では, 3 軸方向に無限に生長した通常 の有機結晶ではなく, リボン様のらせん状繊維やマイク ロチューブといった従来にない中間的な結晶性集合体の 例を紹介した。これら中間結晶相は水素結合ネットワー クの変換により従来の三次元結晶構造も提供した。水素 結合の数と方向性を制御することにより自己集積体の表
面結晶性を制御し，それを駆動力として集積形態自身を 制御できる可能性を示した。ここでは，筆者らの研究27) を中心に解説したが，水素結合の奥深さはこの拙論では 到底語りきれない。ぜひとも，他のすぐれた解説書5, 28) を参考にして頂ければと思う。

\section{謝辞}

本稿の双頭型脂質に関する研究は, 増田光俊, 小木曽 真樹各研究員, 浅川真澄博士（物質研 : ポリマーオブジ エクトグループ), 後藤みどり, 本田一匡, 芝上基成, 八瀬清志各博士 (物質研), M. Mueller 博士 (ETH, ス イス）との共同研究によるものであり,ここに厚く感謝 申し上げる。

\section{文献}

1) 例えば, J.H. Fendler: "Membrane Mimetic Chemistry" (Wiley, New York, 1982).

2) J.N. Israelachvili:"Intermolecular and Surface Forces" (Academic Press, New York, 1985); “分子間力と表面 力”, 近藤, 大島訳 (マグロウヒル，1991).

3) J.-H. Fuhrhop: Chem. Rev. 93, 1565 (1993).

4) J.-H. Fuhrhop, P. Schnieder, E. Boekema and W. Helfrich: J. Am. Chem. Soc. 110, 2861 (1988); J.-H. Fuhrhop and C. Boettcher: J. Am. Chem. Soc. 112, 1768 (1990); J.-H. Fuhrhop, S. Svenson, C. Boettcher, E. Roessler and H.-M. Vieth: J. Am. Chem. Soc. 112, 4307 (1990); J. Koening, C. Boettcher, H. Winkler, E. Zeitler, Y. Talmon and J.-H. Fuhrhop: J. Am. Chem. Soc. 115, 693 (1993).

5) G.A. Jeffrey and W. Saenger: "Hydrogen Bonding in Biological Structures” (Springer-Verlag, Berlin, 1991).

6) J.-M. Lehn: Makromol. Chem. Macromol. Symp. 69, 1 (1993).

7) J.M. Whiteside, E.E. Simanek, J.P. Mathias, C.T. Set, D. N. Chin, M. Mammen and D.N. Gordon: Acc. Chem. Res. 28, 37 (1995).

8) P. Brunet, M. Simard and J.D. Wuest: J. Am. Chem. Soc. 119, 2737 (1997).

9) J.-H. Fuhrhop, H.-H. David, J. Mathieu, U. Liman, H.-J. Winter and E. Boekema: J. Am. Chem. Soc. 108, 1785 (1986).

10) T. Shimizu and M. Masuda: Mol. Cryst. Liq. Cryst. 295, 197 (1997).

11) T. Tachibana, T. Yoshizumi and K. Hori: Bull. Chem. Soc. Jpn. 52, 34 (1979); N. Nakashima, S. Asakuma and T. Kunitake: J. Am. Chem. Soc. 107, 509 (1985).

12) T. Shimizu and M. Masuda: J. Am. Chem. Soc. 119, 2812 (1997).

13) N. Garti and K. Sato: "Crystallization and Polymorphism of Fats and Fatty Acids" (Marcel Dekker, New York, 1988).

14) M. Goto: J. Jpn. Oil Chem. Soc. 19, 583 (1970); N. Yamada and M. Kawasaki: J. Chem. Soc., Perkin Trans. 


\section{2, 2707 (1996).}

15) M. Masuda and T. Shimizu: Chem. Commun. 1057 (1996); M. Masuda and T. Shimizu: Carbohydr. Res. 302, 139 (1997).

16) T. Shimizu, M. Shibakami and M. Masuda: Chem. Lett. 267 (1997).

17) G.A. Jeffrey and L.M. Wingert: Liquid Crystals 12, 179 (1992); 例えば, P.C. Moews and J.R. Knox: J. Am. Chem. Soc. 98, 6628 (1976).

18) 今栄東洋子: 化学 51, 532 (1996); P. Terech, V. Rodriguez, J.D. Barnes and G.B. Mckenna: Langmuir 10, 3406 (1994); P. Terech, I. Furman and R.G. Weiss: J. Phys. Chem. 99, 9558 (1995).

19) F.M. Menger and S.J. Lee: J. Am. Chem. Soc. 116, 5987 (1994).

20) K. Yase, E. Zellman, M. Mueller, M. Masuda and T. Shimizu: Thin Solid Films, 投稿中。

21) T. Shimizu, M. Kogiso and M. Masuda: Nature 383, 487 (1996).

22) K. Yamada, H. Ihara, T. Ide, T. Fukumoto and C.
Hirayama: Chem. Lett. 1713 (1984); J.H. Georger and P. Yager: Biophys. J. 48, 899 (1985); J.-H. Fuhrhop, D. Spiroski and C. Boettcher: J. Am. Chem. Soc. 115, 1600 (1993).

23) M.E. Feinstein and H.L. Rosano: J. Phys. Chem. 73, 601 (1969); W.R. Hargreaves and D.W. Deamer: Biochemistry, 17, 3759 (1978).

24) M. Kogiso, M. Masuda, K. Yase and T. Shimizu: Polymer Preprints, Japan 46, 3303 (1997).

25) T. Shimizu, M. Kogiso and M. Masuda: J. Am. Chem. Soc. 119, 6209 (1997).

26) F.H.C. Crick and A. Rich: Nature 176, 780 (1955).

27) T. Shimizu, M. Masuda, M. Kogiso and M. Asakawa: Kobunshi Ronbunshu 54, 815 (1997).

28) W. Saenger: "Principles of Nucleic Acid Structure" (Springer-Verlag, New York, 1984); “核酸構造”, 西村 訳 (シュプリンガー・フェアラーク東京, 東京, 1987); J.-H. Fuhrhop and J. Koening: "Membranes and Molecular Assemblies: The Synkinetic Approach" (The Royal Society of Chemistry, London, 1994). 